\title{
Consanguinity among the Saudi Arabian population
}

Mohsen A F El-Hazmi, A R Al-Swailem, A S Warsy, A M Al-Swailem, R Sulaimani, A A Al-Meshari

\section{Abstract}

This study was conducted on 3212 Saudi families to investigate the prevalence of consanguineous marriages. The families were interviewed and the information on the relationship between the husband and wife was obtained. The overall rate of consanguinity shows that $\mathbf{5 7 \cdot 7 \%}$ of the families screened were consanguineous. The most frequent were first cousin marriages $(28 \cdot 4 \%)$ followed by distant relative marriages $(15 \cdot 2 \%)$ and second cousin marriages $(14 \cdot 6 \%)$.

The families were grouped according to the province of their origin and the consanguinity rates were calculated accordingly. There were slight differences in the consanguinity rates in the five provinces, which ranged from $52 \cdot 1 \%$ to $67 \cdot 7 \%$. In each province first cousin marriages were the most frequently encountered pattern, ranging from $17.9 \%$ to $40.9 \%$. The inbreeding coefficient $(F)$ was calculated for each province and ranged from 0.020 to 0.030 .

Within each province, there were several significant differences among the populations in the different areas. The highest rate of consanguinity was $80.6 \%$ in Samtah and the lowest rate was around $34 \%$ in Abha in the South Western province.

These results place Saudi Arabia among the countries of the world with a high rate of consanguinity. The possible consequences of increased consanguinity are presented and discussed.

( $($ Med Genet 1995;32:623-626)

Consanguinity refers to the marriage of parents with a recent common ancestor. Consanguineous mating (inbreeding) is an important

Table 1 The prevalence of consanguinity in the Middle East

\begin{tabular}{|c|c|c|c|c|c|}
\hline \multirow[t]{2}{*}{ Country } & \multicolumn{4}{|c|}{ Consanguinity (\%) } & \multirow[t]{2}{*}{ Reference } \\
\hline & 1st degree & 2nd degree & Others & Total & \\
\hline \multicolumn{6}{|l|}{ Saudi Arabia } \\
\hline CP & $29 \cdot 8$ & $13 \cdot 4$ & $17 \cdot 6$ & $60 \cdot 8$ & This study \\
\hline $\begin{array}{l}\text { NP } \\
\text { NWP }\end{array}$ & $17 \cdot 9$ & $17 \cdot 4$ & $17 \cdot 4$ & $52 \cdot 1$ & \\
\hline $\begin{array}{l}\text { NWP } \\
\text { SWP }\end{array}$ & $\begin{array}{l}27 \cdot 3 \\
26 \cdot 0\end{array}$ & $\begin{array}{l}20 \cdot 8 \\
12 \cdot 4\end{array}$ & $19 \cdot 6$ & $67 \cdot 7$ & \\
\hline EP & $40 \cdot 9$ & $\begin{array}{r}12 \cdot 4 \\
9 \cdot 1\end{array}$ & $\begin{array}{r}12 \cdot 4 \\
9 \cdot 1\end{array}$ & $\begin{array}{l}54 \cdot 2 \\
59 \cdot 1\end{array}$ & \\
\hline Egypt & $14 \cdot 10$ & $5 \cdot 40$ & $9 \cdot 46$ & 28.96 & 9 \\
\hline Jordan & $35 \cdot 38$ & $3 \cdot 47$ & $11 \cdot 38$ & $50 \cdot 23$ & 10,11 \\
\hline Kuwait & $32 \cdot 2$ & 0.8 & $21 \cdot 3$ & $54 \cdot 3$ & 12 \\
\hline Iraq & $30 \cdot 0$ & - & - & $57 \cdot 9$ & 8 \\
\hline Bahrain & $21 \cdot 0$ & $7 \cdot 8$ & $10 \cdot 6$ & $39 \cdot 4$ & 13 \\
\hline \multicolumn{6}{|l|}{ Lebanon } \\
\hline Muslims & $17 \cdot 3$ & - & - & $29 \cdot 6$ & \\
\hline Christians & $7 \cdot 9$ & - & - & $16 \cdot 5$ & \\
\hline UAE & $31 \cdot 5$ & - & $30 \cdot 1$ & $61 \cdot 6$ & 14 \\
\hline
\end{tabular}

phenomenon genetically as it brings about an increase in homozygous genotypes and a decrease in the corresponding heterozygous form. ${ }^{1}$ Consanguinity is common in several populations of the world though the consanguinity rates vary from one population to another. Furthermore, there is variability between different tribes, communities, and ethnic groups within the same country. ${ }^{2}$ Worldwide, a wide variation in the consanguinity rates among various ethnic groups have been reported. In European populations the rates are generally less than $0.5 \%$, while in North Africa and southern and western Asian populations 22 to $55 \%$ of all unions are consanguineous. ${ }^{13}$ In the majority of the US States cousin marriages are illegal under the statutes passed in the 19 th and 20 th centuries. ${ }^{3}$

In the Arabian populations several studies have shown that consanguinity varies between and within each country with a wide range of prevalence. Reports from Saudi Arabia indicated significant differences. Chaleby and Tuma $^{4}$ encountered $18.9 \%$ consanguinity in hospital visitors compared to $31.4 \%$ in obstetrics inpatients. ${ }^{5}$ More recently, in a study of 500 females, the consanguinity rate was shown to be $50 \%$ in Riyadh. ${ }^{6}$ Reports from the other Arab populations also show a high rate of consanguinity, ranging from $10.6 \%$ in Bahrain $^{7}$ to $56.4 \%$ in Iraq ${ }^{8}$ (table 1 ), though a more recent report from Bahrain shows a prevalence of $39 \cdot 4 \% .^{13}$

Although consanguinity is associated with increased gross fertility, morbidity and mortality are shown to be higher, thus resulting in comparable numbers of surviving offspring in both consanguineous and non-consanguineous matings. ${ }^{3}$ Several genetic disorders, congenital malformations, and reproductive wastage are more frequent in consanguineous marriages. ${ }^{3412} \mathrm{~A}$ study on heriditary hearing impairment, an autosomal resessive disorder,

Received 20 December 1994
College of Medicine, King Khalid University Hospital, Riyadh

Saudi Árabia

R Sulaimani

Department of

Obstetrics and

Gynaecology,

College of Medicine,

King Khalid

University Hospital, Riyadh

Saudi Árabia

A A Al-Meshari

Correspondence to:

Professor El-Hazmi. Revised version accepted for publication 4 April 1995

Department of
Medical Biochemistry,
King Khalid University
Hospital (30),
PO Box 2925,
Riyadh 11461,
Saudi Arabia
M A F El-Hazmi
Ministry of Health,
Riyadh,
Saudi Arabia
A R Al-Swailem
A M Al-Swailem
Department of
Biochemistry,
College of Science,
King Saud University,
Riyadh,
Saudi Arabia
A S Warsy
Department of
Medicine,
College of Medicine,
King Khalid
University Hospital,
Riyadh,
Saudi Arabia
R Sulaimani
Department of
Obstetrics and
Gynaecology,
College of Medicine,
King Khalid
University Hospital,
Riyadh,
Saudi Arabia
A A Al-Meshari
Correspondence to:
Professor El-Hazmi.
Received 20 December 1994
Revised version accepted for
publication 4 April 1995




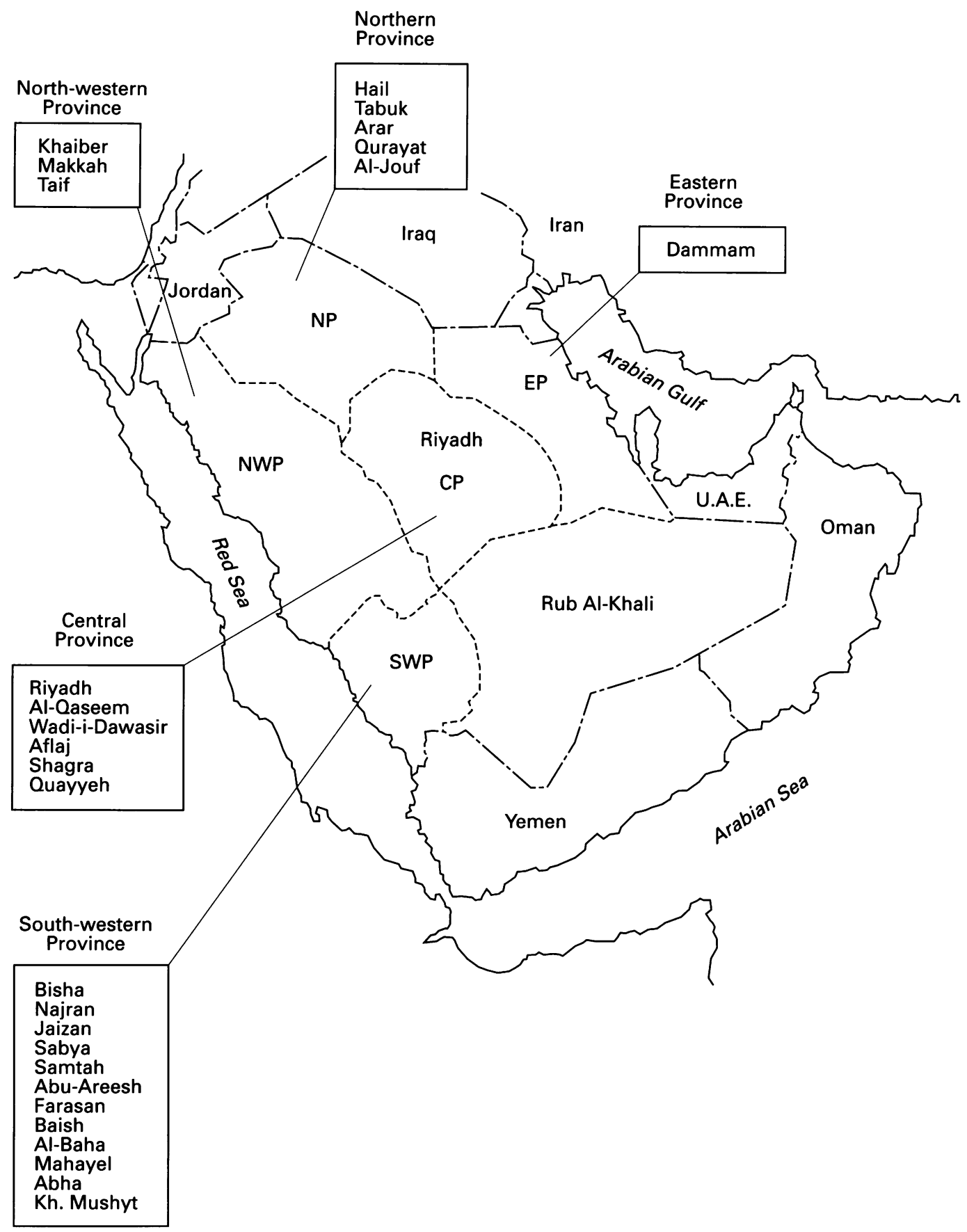

Sketch map of Saudi Arabia showing the areas screened during the study.

showed that the disorder occurred more often in consanguineous matings in Saudi Arabia. ${ }^{15} \mathrm{~A}$ high prevalence of inborn errors of metabolism and congenital malformations in Saudis is believed to result from a high rate of consanguinity, ${ }^{1617}$ though the relationship between consanguinity and other genetic diseases awaits studies of consanguineous and non-consanguineous marriages in Saudis.

We initiated this study to determine the prevalence of consanguinity in the Saudi population in different parts of the country and to compare the results with those reported in other Arabs and neighbouring populations.

\section{Materials and methods}

The study was conducted in different areas of Saudi Arabia according to a statistically de- signed household screening plan, during a national study to determine the prevalence of diabetes mellitus in Saudi Arabia (Project No AT-MW-10). Each area was divided into sectors and randomly distributed sectors were selected for screening. In every sector every tenth street, and on every street every tenth house, was selected for screening. The local health centre was contacted to obtain essential information on the household. Thereafter, the family was contacted and invited to participate in the study. The visit was made by the investigators and one technical staff and a nurse on a mutually agreed day. Fewer than $5 \%$ of the families contacted declined to be included in the study. A total of 3212 Saudi families participated in the study; they lived in different areas of Saudi Arabia as shown in the sketch map (figure). A purpose designed questionnaire 
Table 2 Rate of consanguineous marriages in different provinces of Saudi Arabia

\begin{tabular}{|c|c|c|c|c|c|c|}
\hline \multirow[t]{2}{*}{ Province } & \multirow{2}{*}{$\begin{array}{l}\text { No of families } \\
\text { investigated }\end{array}$} & \multicolumn{4}{|c|}{ Consanguinity prevalence (\%) } & \multirow[t]{2}{*}{$F$} \\
\hline & & 1st degree & 2nd degree & Others & Total & \\
\hline $\begin{array}{l}\text { Central } \\
\text { Northern } \\
\text { North western } \\
\text { South western } \\
\text { Eastern } \\
\text { Total }\end{array}$ & $\begin{array}{r}1108 \\
693 \\
391 \\
998 \\
22 \\
3212\end{array}$ & $\begin{array}{l}29 \cdot 8 \\
17 \cdot 9 \\
27 \cdot 3 \\
26 \cdot 0 \\
40 \cdot 9 \\
25 \cdot 8\end{array}$ & \begin{tabular}{r|}
$13 \cdot 4$ \\
$17 \cdot 4$ \\
$20 \cdot 8$ \\
$12 \cdot 4$ \\
$9 \cdot 1$ \\
$14 \cdot 8$
\end{tabular} & $\begin{array}{r}17 \cdot 6 \\
17 \cdot 4 \\
19 \cdot 6 \\
12 \cdot 4 \\
9 \cdot 1 \\
16 \cdot 2\end{array}$ & $\begin{array}{l}60 \cdot 8 \\
52 \cdot 1 \\
67 \cdot 7 \\
54 \cdot 2 \\
59 \cdot 1 \\
56 \cdot 8\end{array}$ & $\begin{array}{l}0.0258 \\
0.0206 \\
0.0283 \\
0.0229 \\
0.0302 \\
0.0241\end{array}$ \\
\hline
\end{tabular}

$\mathrm{F}=$ inbreeding coefficient.

Table 3 Prevalence of consanguinity in different areas in each province

\begin{tabular}{|c|c|c|c|c|c|}
\hline \multirow{2}{*}{$\begin{array}{l}\text { Provincel } \\
\text { area }\end{array}$} & \multirow{2}{*}{$\begin{array}{l}\text { No of families } \\
\text { investigated }\end{array}$} & \multicolumn{4}{|c|}{ Prevalence (\%) } \\
\hline & & 1st degree & 2nd degree & Others & Total \\
\hline \multicolumn{6}{|l|}{ Eastern } \\
\hline Dammam & 22 & $40 \cdot 9$ & $9 \cdot 1$ & $9 \cdot 1$ & $59 \cdot 1$ \\
\hline $\begin{array}{l}\text { Northern } \\
\text { Hail }\end{array}$ & 289 & $17 \cdot 6$ & $8 \cdot 3$ & $18 \cdot 0$ & 43.9 \\
\hline Tabuk & 205 & $17 \cdot 1$ & $17 \cdot 1$ & 9.5 & 43.7 \\
\hline Arar & 103 & $23 \cdot 3$ & $40 \cdot 8$ & $8 \cdot 7$ & $72 \cdot 8$ \\
\hline Qurayat & 50 & $8 \cdot 0$ & $18 \cdot 0$ & $22 \cdot 7$ & $48 \cdot 7$ \\
\hline \multicolumn{6}{|l|}{$\begin{array}{l}\text { Al-Jouf } \\
\text { Central }\end{array}$} \\
\hline $\begin{array}{l}\text { Rentral } \\
\text { Riyadh }\end{array}$ & 473 & $40 \cdot 4$ & $9 \cdot 3$ & $13 \cdot 1$ & $62 \cdot 8$ \\
\hline W Dawasir & 30 & $16 \cdot 7$ & $6 \cdot 7$ & $13 \cdot 3$ & $36 \cdot 7$ \\
\hline Aflaj & 50 & $22 \cdot 0$ & $24 \cdot 0$ & $28 \cdot 0$ & $74 \cdot 0$ \\
\hline Shagra & 64 & $28 \cdot 1$ & $10 \cdot 9$ & $28 \cdot 1$ & $67 \cdot 1$ \\
\hline Quayyah & 50 & $38 \cdot 0$ & $8 \cdot 0$ & $22 \cdot 0$ & $68 \cdot 0$ \\
\hline Al-Qaseem & 441 & $19 \cdot 5$ & $18 \cdot 1$ & $19 \cdot 5$ & $57 \cdot 1$ \\
\hline \multicolumn{6}{|l|}{ South western } \\
\hline Abha & 70 & $8 \cdot 6$ & $10 \cdot 0$ & $15 \cdot 7$ & $34 \cdot 3$ \\
\hline Mahayel & 24 & $16 \cdot 7$ & $29 \cdot 2$ & $20 \cdot 8$ & $66 \cdot 7$ \\
\hline Bisha & 29 & $20 \cdot 7$ & $17 \cdot 2$ & $13 \cdot 8$ & $51 \cdot 7$ \\
\hline Kh Mushyt & 54 & $20 \cdot 4$ & $14 \cdot 8$ & $5 \cdot 6$ & $40 \cdot 8$ \\
\hline Jaizan & 52 & $30 \cdot 8$ & $23 \cdot 1$ & $5 \cdot 8$ & $59 \cdot 7$ \\
\hline Sabya & 89 & $24 \cdot 7$ & $16 \cdot 9$ & $11 \cdot 2$ & $52 \cdot 6$ \\
\hline Samtah & 45 & $40 \cdot 0$ & $22 \cdot 2$ & $24 \cdot 4$ & $86 \cdot 6$ \\
\hline AbuArish & 47 & $19 \cdot 0$ & $12 \cdot 8$ & $12 \cdot 8$ & $44 \cdot 0$ \\
\hline Farasan & 23 & $13 \cdot 0$ & $13 \cdot 0$ & $26 \cdot 0$ & $52 \cdot 0$ \\
\hline Baish & 21 & $38 \cdot 1$ & $9 \cdot 5$ & $4 \cdot 8$ & $52 \cdot 4$ \\
\hline Al-Baha & 356 & $36 \cdot 2$ & $3 \cdot 1$ & $23 \cdot 9$ & $63 \cdot 2$ \\
\hline Najran & 188 & $26 \cdot 6$ & $26 \cdot 6$ & $7 \cdot 4$ & $60 \cdot 6$ \\
\hline \multicolumn{6}{|l|}{ North western } \\
\hline Makkah & 34 & $20 \cdot 6$ & $14 \cdot 7$ & $8 \cdot 8$ & $44 \cdot 1$ \\
\hline Taif & 166 & $24 \cdot 1$ & $28 \cdot 9$ & $14 \cdot 5$ & $67 \cdot 5$ \\
\hline Khaiber & 191 & $32 \cdot 6$ & $12 \cdot 8$ & $28 \cdot 4$ & $73 \cdot 8$ \\
\hline
\end{tabular}

was filled in by an Arabic speaking interviewer. The questionnaire included an enquiry about the family relationship of the husband and wife and the level of consanguinity, if any (that is, first cousin, second cousin, or others). Further subdivision was carried out according to the origin of each family within the province. The data were fed into the computer and compared and contrasted with the rate of consanguineous and non-consanguineous marriages.

\section{Results}

Of the total 3212 families included in this investigation, 1852 were found to be consanguineous, an overall rate of consanguinity of $57.7 \%$. In the five provinces the rates of consanguinity ranged from $52 \cdot 1 \%$ to $67 \cdot 7 \%$, and in each province first cousin marriages were generally the favoured type (table 2).

Within each province the different localities were separated and the prevalence of consanguinity was calculated in each area. Differences were encountered in the consanguinity rates in each area (table 3 ), where the minimum rate was around $34.3 \%$ in Abha and the highest was $86.6 \%$ in Samtah, both in the Southern Province. In addition, differences were also observed in the prevalence of first cousin, second cousin, and other forms of marriage between relatives. In most areas first cousin marriages were more prevalent, while in others second cousin marriage occurred at a higher prevalence. In some areas other forms of marriage between relatives were more common (table 3 ). The inbreeding coefficient $(F)$ was calculated for each province and ranged from 0.02 to 0.03 . The average inbreeding coefficient in the overall Saudi population was 0.024 .

\section{Discussion}

This study shows the prevalence of consanguinity in Saudi Arabia and places Saudi Arabia in the same rank as Kuwait, ${ }^{18}$ Jordan, ${ }^{1011}$ Iraq, ${ }^{8}$ Pakistan, ${ }^{19}$ Egypt, ${ }^{9021}$ and the United Arab Emirates. ${ }^{14}$ The consanguinity rates in Saudi Arabia and other Arab countries are significantly higher than in the South and North Americans, Europeans, South Africans, eastern Asians, and the populations in the Oceanic countries. ${ }^{2}$

Within Saudi Arabia the prevalence of consanguineous marriages differs from one area to another. First cousin marriages occur at the highest prevalence in most of the regions, though in some of the regions second cousin and other marriages between relatives are observed at a high rate.

The inbreeding coefficient (F) also placed Saudi Arabia among the countries of the world with a high rate of inbreeding. In western coun- 
tries where consanguineous mating occurs at a low frequency, the inbreeding coefficient is low, for example in Canada (Roman Catholics) $\mathrm{F}=$ $0 \cdot 00004-0 \cdot 0007$, in the United States (Roman Catholics) $\mathrm{F}=0-0.0008$, in Latin America, $\mathrm{F}=$ $0-0.003$, in southern Europe, $F=0.001-0.002$, and in Japan $F=0.005$. However, in populations with higher consanguinity rates the values are higher, for example, in India (Andra Pradesh) $F=0.02$ and in the Samaritans, a group numbering only around 500 people who have been genetically isolated for over 3000 years, $\mathrm{F}=0 \cdot 04$. $^{1}$ Saudi Arabia, with a range around $0.02-0.03$ and an average of 0.024 , occupies an intermediate position.

There are several underlying factors which may operate to encourage consanguineous marriages. In Saudi Arabia, the high rate of consanguinity may be attributed to social and traditional factors and to the desire to keep property within families. Similar indications are shown in a neighbouring country with similar customs and beliefs. The main factors that inspire consanguinity include social and economic benefits and more stable marriages among cousins, where the male and female grow up in the same or similar environment of the family and therefore adjust more easily after the marriage. In addition, marriage between relatives is considered beneficial as it maintains the family fortunes within the same family structure. Anthropologists have long agreed that the main achievement of consanguineous marriages is the inheritance of family structure and property. ${ }^{22-24}$

Several studies have described aspects of reproductive behaviour, reproductive wastage, morbidity and mortality, and genetic effects of consanguineous matings. The major harmful effect of consanguinity is a higher frequency of autosomal recessive diseases in the offspring and frequently an increased rate of morbidity and mortality. The excess mortality is shown to be directly related to the degree of inbreeding. ${ }^{91420-24}$ In addition, congenital malformations and inborn errors are believed to occur at a higher prevalence in cousin marriages. ${ }^{1617}$

In Saudi Arabia, several genetic disorders (mostly autosomal and $\mathrm{X}$ linked recessive) are prevalent. The most thoroughly investigated are sickle cell disease, haemoglobinopathies, and enzymopathies (glucose-6-phosphate dehydrogenase deficiency). ${ }^{25-27}$ People with two or more of these abnormal genes are frequently encountered and interaction between these genes influencing the clinical presentation are common. ${ }^{2829}$ The number of homozygous cases, for example, sickle cell anaemia and glucose-6-phosphate dehydrogenase (G6PD) deficient females, observed in the different areas of Saudi Arabia is significantly higher compared to the number of expected cases obtained using Hardy-Weinburg equilibrium. ${ }^{30}$ This disturbance of Hardy-Weinburg equilibrium is believed to be because of the high rate of consanguinity in the Saudi population. Little information is available on the prevalence of other genetic disorders and congenital anomalies, but these disorders are not uncommon. ${ }^{1516}$

Further studies are under way to determine the consanguinity rates in relation to morbidity and mortality in this population, and may show other interesting findings and correlations.

This study was supported in part by grant No AT-MW-10 from King Abdulaziz City for Science and Technology and partly by King Saud University.

1 Thompson MW, McInnes RR, Willard HF. Genetics in medicine. 5th ed. London: Saunders, 1991

2 Bittles AH. Consanguineous marriages; current global incidence and its relevance to demographic research. Research report No 90-186. Ann Arbor: Population Studies Center, 1990.

3 Bittles AH, Mason WM, Greene J, Rao NA. Reproductive behavior and health in consanguineous marriages. Science 1991;252:789-94.

4 Chaleby K, Tuma TA. Cousin marriages and schizophrenia in Saudi Arabia. Br f Psychiatry 1987;150:547-9.

5 Saedi-Wong S, Al-Frayh RA, Wong NYH. Socio-economic epidemiology of consanguineous mating in the Saudi Arabian population. F Asian Afr Studies 1989;24:247-51.

6 Al-Hussein M, Al-Bunyan M. Rate of consanguineous mar$\mathrm{Al}-$ Hussein M, Al-Bunyan M. Rate of consanguineous mar-
riages in Saudi population. Symposium on Medical Genetics riages in Saudi population. Symposium on Medical Genetics
in the Setting of Middle Eastern Populations, Riyadh, 1993A. 7 El-Shafei A, Rao PSS, Samdhu AK. Congenital malEl-Shafei A, Rao PSS, Samdhu AK. Congenital mal-
formations and consanguinity. Aust NZ F Obstet Gynaecol 1986;26:168-72.

8 Hamamy HA, Al-Hakkak ZS. Consanguinity and reproductive health in Iraq. Hum Hered 1989;39:271-5.

9 Hafez M, El-Tahan $\mathrm{H}$, Awadalla M, El-Khayat $\mathrm{H}$, AbdelGafar A, Ghoneim M. Consanguineous matings in the Egyptian population. $\mathcal{f}$ Med Genet 1983;20:58-60.

10 Cook R, Hanslip A. Mortality among offspring of consanguineous marriage in a rural area of East Jordan. $\mathscr{f}$ Trop Pediatr 1966;11:95-9.

11 Khoury SA, Massad D. Consanguineous marriage in Jordan. Am F Med Genet 1992;43:769-75.

12 Al-Awaidi SA, Naguib KK, Moussa MA, Farag TI, Teebi AS, El Khalifa MY. The effect of consanguineous marriages on reproductive wastage. Clin Genet 1986;29:384-8.

$13 \mathrm{Al}$-Arrayed S. Consanguinity in the State of Bahrain. Symposium on Medical Genetics in the Setting of Middle Eastern
Populations, Riyadh, 1993A.

14 Fahmy NA, Benson PF, Al-Garrah DB. Consanguinity in UAE: prevalence and analysis of some risk factors. Emirate Med fै 1993;1:39-41.

15 Zakzouk S, El-Sayed Y, Bafaqeeh SA. Consanguinity and hereditary hearing impairment among Saudi population. Ann Saudi Med 1993;13:447-50.

16 Ozand PI, Rashed MS. Inborn errors of metabolism in the Middle East. Symposium on the Epidemiological Transition/ Transaction and Health in Developing Countries, Riyadh, 1994A.

17 Sakati $\mathrm{N}$. Congenital malformation as a health problem model in developing countries. Symposium on the Epidemiological Transition/Transaction and Health in Developing Countries, Riyadh, 1994A.

18 Al-Awadi SA, Moussa MA, Naguib KK, et al. Consanguinity among the Kuwaiti population. Clin Genet 1985;27:483-6.

19 Shami SA, Schmitt LH, Bittles AH. Consanguinity, spousal age at marriage and fertility in seven Pakistani Punjab age at marriage and fertility in seven
cities. Ann Hum Biol 1990;17:97-105.

20 Badr FM. Genetic studies of Egyptian Nubian population. Frequency of types of consanguineous marriages. Hum Frequency of types of
Hered 1972;22:387-8.

21 Hussein FH. Endogamy in Egyptian Nubia. $\mathcal{f}$ Biosoc Sci 1971;3:351-7.

22 Granguist H. Marriage conditions in a Palestinian village. Parts I \& III. Helsinki: Soderstrom, 1931.

23 Resonfeld $\mathrm{H}$. An analysis of marriage and marriage statistics for a muslim and Christian Arab village. Int Arch Ethnogr 1957;68:32.

24 Schull WJ, Neel JV. The effects of parental consanguinity and inbreeding in Hirado, Japan. V. Summary and interpretation. Am $\mathcal{F}$ Hum Genet 1972;24:425-53.

25 El-Hazmi MAF. Haemoglobin disorders: a pattern for thalassaemia and haemoglobinopathies in Arabia. Acta Haematol 1982;68:43-51.

26 El-Hazmi MAF. Haemoglobinopathies, thalassaemias and enzymopathies in Saudi Arabia: the present status. Acta Haematol 1987;78:130-4.

27 El-Hazmi MAF. Haemoglobinopathies, thalassaemias and enzymopathies in Saudi Arabia. Saudi Med $\mathcal{F} 1992 ; 13$ : 488-99.

28 El-Hazmi MAF, Warsy AS. On the molecular interactions between thalassaemia and sickle cell gene. $\mathcal{f}$ Trop Pediatr between thalassa

29 El-Hazmi MAF, Warsy AS, Al-Swailem AR, Al-Faleh FZ, Al-Jabbar FA. Genetic compounds-Hb S, thalassaemias
and enzymopathies: spectrum of interactions. $\mathcal{F}$ Trop $P e-$ and enzymopathies: spect

30 El-Hazmi MAF, Warsy AS. Frequency of sickle cell gene in Saudi Arabia. Hemoglobin (in press) 